\title{
Kontrol Stepsize Pada Integrasi Numerik Ekivalen Dengan Prinsip Aksi Kontroler PID Pada Sistem Kontrol
}

\author{
Tio Dewantho Sunoto ${ }^{1}$
}

\begin{abstract}
Differential equations with initial values are used as mathematical models to express problems in the fields of physics, engineering, biology or others. The achievement of differential equations solutions is mostly done through a numerical integration method approach. Stepsize control on numerical integration method will affect the accuracy and efficiency of the solution, and many stepsize control approaches are carried out proportionally and statically even though it is known that the problems reviewed are dynamic. That in the field of control systems there are P, PI, PD or PID controllers that can be static and dynamic and proportional action controls have the disadvantage of not being able to eliminate errors in steady-state conditions.

The problem between the stepsize control approach and the PID controller seems to be equivalence and this paper declares the existence of a close analogy of the two problems even though it is limited to theoretical and the numerical test cannot be explained because the research to be continues.
\end{abstract}

KEYWORDS: Stepsize, Numerical Integration, PID Controler.

\begin{abstract}
ABSTRAK: Persamaan diferensial dengan nilai awal (initial value problem) banyak digunakan sebagai model matematik untuk menyatakan permasalahan baik dalam bidang fisika, rekayasa, biologi atau lainnya. Pencapaian solusi persamaan diferensial tersebut banyak dilakukan melalui pendekatan metode integrasi numerik. Kontrol stepsize pada metode integrasi numerik akan mempengaruhi akurasi dan efisiensi dari solusi, dan banyak pendekatan kontrol stepsize dilakukan secara proporsional dan statik walaupun diketahui permasalahan yang ditinjau bersifat dinamik. Bahwa pada bidang sistem kontrol telah tersedia kontroler P, PI, PD atau PID yang dapat bersifat statik dan dinamik dan diketahui bahwa kontrol aksi proporsional mempunyai kelemahan tak dapat menghilangkan kesalahan pada kondisi steady-state. Permasalahan antara pendekatan kontrol stepsize dengan kontroler PID tampaknya ekivalen dan tulisan ini mendeklarasikan adanya analogi yang erat dari kedua permasalahan tersebut walaupun sebatas teoritis dan uji numeriknya belum dapat dipaparkan karena penelitiannya masih berlanjut.
\end{abstract}

KATA KUNCI: Stepsize, Integrasi Numerik, Kontroler PID.

\section{PENDAHULUAN}

Salah satu masalah dalam analisis numerik adalah merancang dan menganalisis metode integrasi numerik Nyang mengandung parameter-parameter, diantaranya kontrol stepsize yang perlu diatur selama pengintegrasian. Tujuan kontrol stepsize adalah untuk memperoleh keakurasian dari estimasi solusi sesuai dengan persyaratan yang ditentukan. Bilamana pemilihan stepsize terlalu besar, hasil perkiraan solusinya akan mempunyai kesalahan yang cukup besar dan bila terlalu kecil maka akurasi hasilnya akan tinggi tetapi jumlah langkah pengintegrasian menjadi tidak efisien.

Pendekatan umum yang dilakukan untuk memperoleh keakurasian melalui penyesuaian kontrol stepsize yang mengestimasi batasan kesalahan dari setiap langkah pengintegrasian, dan pemilihan stepsize akan mempengaruhi kesalahan global dari solusi hasil estimasi. Permasalahan muncul antara akurasi yang harus dicapai, kontrol stepsize yang perlu dilakukan dan efisiensi dari jumlah komputasi. Pada umumnya algoritma/program yang dibuat untuk mencari pendekatan solusi numerik adalah memuaskan, tetapi kadang kala mengecewakan walau kondisinya sederhana seperti contoh untuk simulasi solusi Brusselator [1].

\section{METODE INTEGRASI NUMERIK}

Metode pengintegrasian numerik sebagai langkah persiapan yang perlu diambil sehingga perhitungan numerik dapat dilaksanakan dan berikut ini gambaran singkat tentang metode pengintegrasian numerik [1]. Tinjau masalah nilai awal berikut,

$$
\dot{y}=f(t, y), \quad y\left(t_{0}\right)=y_{0}, \quad t \in\left[t_{0}, t_{\text {end }}\right]
$$

dengan $y(t)$ solusi yang sebenarnya.

Pendekatan metode integrasi persamaan (1) melalui persamaan diferensial,

$$
y_{n+1}=\bar{y}_{n}+h_{n} \bar{f}_{n}, \quad n=0,1,2, \ldots
$$

$\bar{y}_{n}$ sebagai kombinasi dari titik-titik solusi sebelumnya, $\bar{f}_{n}$ sebagai kombinasi dari nilai-nilai yang dihitung pada titik-titik solusi atau sekitar titik-titik solusi. Persamaan (2) dipakai untuk menghitung $y_{0}, y_{1}, y_{2}, \ldots$ sebagai nilai pendekatan untuk $y\left(t_{0}\right), y\left(t_{1}\right), \ldots$.

Stepsize $h_{\mathrm{n}}$ bertalian dengan titik-titik solusi dan didefinisikan dengan $t_{\mathrm{n}+1}=t_{\mathrm{n}}+h_{\mathrm{n}}$, ukuran $h_{\mathrm{n}}$ bervariasi sepanjang solusi persamaan diferensial sesuai dengan persyaratan akurasi dan efisiensi. Kontrol stepsize dibuat sebesar mungkin agar jumlah langkah penghitungan sedikit tapi harus memenuhi persyaratan akurasi, kesulitan terjadi saat kontrol stepsize ditetapkan dan harus memenuhi kriteria akurasi dan kesalahan tertentu.

Metode implisit s-langkah Runge-Kutta dari bahasan sebelumnya [2] :

$$
\bar{y}_{n}=y_{n}, \quad \bar{f}_{n}=\sum_{j=1}^{s} b_{j} f\left(t_{n}+c_{j} h_{n}, Y_{j}\right)
$$

\footnotetext{
${ }^{1}$ Jurusan Teknik Elektro, Universitas Kristen Maranatha, Bandung.
} 


$$
Y_{j}=y_{n}+h_{n} \sum_{j=1}^{s} a_{i j} f\left(t_{n}+c_{j} h_{n}, Y_{j}\right)
$$

$Y_{i}, i=1, \ldots s$, nilai-nilai perhitungan.

Koefisien $\left\{a_{i j}\right\},\left\{b_{j}\right\}$ dan $\left\{c_{j}\right\}$ dipilih sehingga ekspansi deret Taylor dari solusi numerik $y_{n}$ sesuai dengan bentuk yang berlaku pada ekspansi solusi sebenarnya $y\left(t_{\mathrm{n}}\right)$.

Terdapat dua formula dari orde $k-1$ dan $k$ yang diwakili oleh kelompok koefisien $\left\{b_{j}\right\}$ dan $\left\{\hat{b}_{j}\right\}$ yang dipakai pada persamaan $\bar{f}_{n}$ dengan persamaan estimasi kesalahan,

$$
\hat{e}_{n+1}=h_{n} \sum_{j=1}^{m}\left(b_{j}-\hat{b}_{j}\right) f\left(t_{n}+c_{j} h_{n}, Y_{j}\right)
$$

Bentuk "norm" dipakai untuk membentuk estimasi skalar kesalahan $r$ dan biasanya dipilih

$r=\|\hat{e}\|=\left(\sum_{i}\left(\frac{\hat{e}_{i}}{\left|y_{i}\right|+\eta_{i}}\right)^{2}\right)^{1 / 2}, \eta_{i}$ faktor skala untuk komponen ke $i$ dari $y$.

Secara asimtutik $r=\|\hat{e}\|$ dan mempunyai bentuk,

$$
r_{n+1}=\varphi_{n} h_{n}^{k}
$$

dengan $\varphi_{n}=\left\|\phi\left(t_{n}\right)\right\|, \phi(t)$ berisi elemen diferensial $f$ berorde $k$ atau yang lebih tinggi. Kesalahan harus dijaga di bawah toleransi yang disyaratkan oleh pengguna tol, nilai awal (set-point) $\varepsilon$ untuk mengontrol kesalahan dipilih di bawah $t o l$, biasanya diambil $\varepsilon=0,8 \mathrm{tol}$. Bila $r>\varepsilon$ langkah perhitungan dibuang (reject) dan diulangi untuk pemilihan stepsize yang lebih kecil. $r_{n+1}$ pada persamaan (6) mencapai $\varepsilon$ bila $h_{n}=\left(\varepsilon / \varphi_{n}\right)^{1 / k}$ dan dengan asumsi perubahan $\varphi$ lambat, $\hat{\varphi}_{n}=\varphi_{n-1}=r_{n} / h_{n-1}^{k}$ sehingga :

$$
h_{n}=\left(\frac{\varepsilon}{\left(r_{n}\right)}\right)^{1 / k} h_{n-1}
$$

Dengan menambahkan beberapa faktor keamanan maka Persamaan (7) sebagai aturan kontrol stepsize yang dipakai secara umum [2].

Logaritmik persamaan (7) adalah,

$$
\log h_{n}=\log h_{n-1}+k^{-1}\left(\log \varepsilon-\log r_{n}\right)
$$

Persamaan (8) dikenal sebagai integrasi kontroler, dengan nilai awal $\log \varepsilon$, penguatan integrasi $1 / k$. Lup tertutup dari $\log \varepsilon$ kepada $\log r_{n}$ adalah orde satu, dan pemilihan penguatan integrasi $1 / k$ akan membuat lup deadbeat.

Logaritmik Persamaan (6) adalah $\log r_{n}=k \log h_{n-1}+\log \varphi_{n-1}$, gangguan $\varphi$ dieliminasi oleh integrator dari kontroler, walau asumsinya konstan sebenarnya $\varphi$ bervariasi sepanjang solusi persamaan diferensial dan variasinya bisa sangat besar sehingga kontroler tak mampu menjaga $r \approx \varepsilon$. Pada saat $\varphi$ bertambah besar sekali maka sepanjang sekuen perhitungan terjadi langkah yang dibuang dan yang diambil. Untuk mengatasi situasi ini dilibatkan kontroler yang didasarkan pada model gangguan $\varphi$.

Permasalahan utama Persamaan (7) pada sebuah metode integrasi implisit adalah memakai prediksi $\hat{\varphi}_{n}=\varphi_{n-1}$.

Model sederhana dari gangguan $\varphi$ yang telah dibuktikan efektif [3],

$$
\log \hat{\varphi}_{n}=\log \varphi_{n-1}+\nabla \log \varphi_{n-1}
$$

dengan $\nabla \log \varphi_{n-1}=\log \varphi_{n-1}-\log \varphi_{n-2}$.

Prediksi Persamaan (9) dapat menggunakan prinsip sebuah pengamat (observer) dan menggunakan operator geser $q$,

$$
\log \hat{\varphi}_{n}=\frac{\left(k_{1}+k_{1}\right) q^{2}-k_{1} q}{q^{2}+\left(k_{1}+k_{1}-2\right) q+1-k_{1}} \log \varphi_{n-1}
$$

Penguatan dari pengamat $K$ menentukan dinamika pengamat, dan pengamat dapat diinterpretasikan sebagai pembobotan geometris rata-rata dari nilai-nilai pengukuran sebelumnya. Penguatan $K$ menyatakan berapa banyak pengukuran sebelumnya harus mempengaruhi estimasi. Dengan mengambil $k_{1}=k_{2}=1$ akan mendasari estimasi hanya pada pengukuran yang baru.

Prediksi terhadap gangguan dapat dilakukan dengan memilih kontrol stepsize,

$$
\log h_{n}=k^{-1}\left(\log \varepsilon-\log \hat{\varphi}_{n}\right)
$$

agar dicapai $r_{n+1}=\varepsilon$ pada Persamaan (6).

Persamaan (10) dengan $\varepsilon$ konstan,

$$
\begin{aligned}
& \log h_{n}=H_{R}(q)\left(\log \varepsilon-\log \varphi_{n-1}\right) \\
& H_{R}(q)=\frac{1}{k} \frac{\left(k_{1}+k_{1}\right) q^{2}-k_{1} q}{q^{2}+\left(k_{1}+k_{1}-2\right) q+1-k_{1}}
\end{aligned}
$$

Masukkan persamaan $\log \varphi_{n-1}$ kepada Persamaan (12), didapat

$$
\log h_{n}=\frac{1}{k} \frac{\left(k_{1}+k_{1}\right) q^{2}-k_{1} q}{\left(q_{1}-1\right)^{2}}\left(\log \varepsilon-\log r_{n}\right)
$$

Persamaan (13) dinyatakan dengan notasi Persamaan (7) didapat,

$$
h_{n+1}=\frac{h_{n}}{h_{n-1}}\left(\frac{\varepsilon}{\left(r_{n+1}\right)}\right)^{k_{2} / k}\left(\frac{r_{n}}{\left(r_{n+1}\right)}\right)^{k_{1} / k} h_{n}
$$

Bentuk ini menyatakan kontrol stepsize baru yang berdasarkan pada ekstrapolasi dari kesalahan-kesalahan dan kontrol stepsize sebelumnya. 
Kontrol Stepsize yang baru perlu ditentukan dan pengamat harus memperbarui dengan informasi dari langkah yang dibuang (tak dipakai). Strategi kontroler yang baru ekivalen dengan Persamaan (7), tetapi kondisi pengamat disetel untuk lebih melacak perubahan yang terdapat pada langkah-langkah pengintegrasian. Strategi kontrol stepsize dengan melibatkan konsep kontroler dinyatakan seperti pada Gambar 1. yang dikutip dari hasil penelitian [1].

$$
\begin{aligned}
& \text { if current.step.accept then } \\
& h_{a c c}:=h \\
& \text { If first.step then } \\
& h:=\left(\frac{\varepsilon}{r}\right)^{1 / k} h \\
& \text { else } \\
& h:=\frac{h}{h_{a c c}}\left(\frac{\varepsilon}{r}\right)^{k_{2} / k}\left(\frac{r_{a c c}}{r}\right)^{k_{1} / k} h \\
& \text { endif } \\
& r_{a c c}:=r \\
& h:=\left(\frac{\varepsilon}{r}\right)^{1 / k} h
\end{aligned}
$$

- Gambar 1. Algoritma pemilihan ukuran langkah memakai konsep kontroler baru.

\section{KONTROLER PROPORSIONAL, INTEGRAL DAN DERIVATIF (PID)}

Berikut ulasan singkat dari konsep kontroler Proporsional, Integral dan Derivatif (PID) [4], konsep ini umum digunakan pada sistem berumpan balik, dan sebagai peralatan standar dalam kontrol proses. Pengontrol PID sering dikombinasikan dengan logik, fungsi-fungsi sekuensial, selektor dan blok-blok fungsi sederhana yang membentuk suatu sistem otomasi komplek untuk keperluan produksi energi, transportasi dan bidang manufaktur.

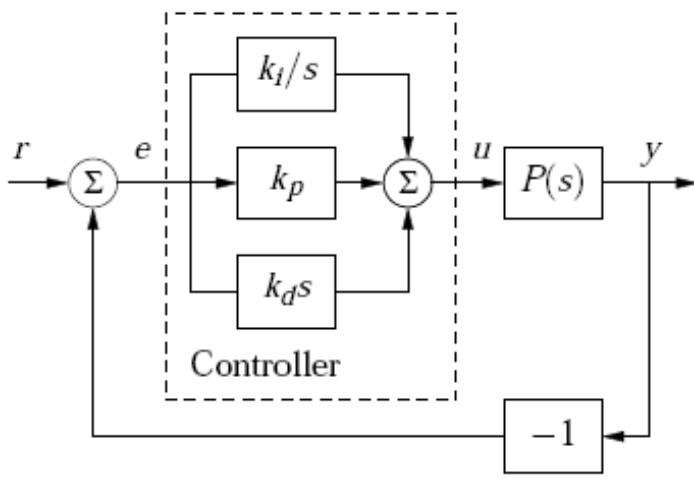

(a) PID using error feedback

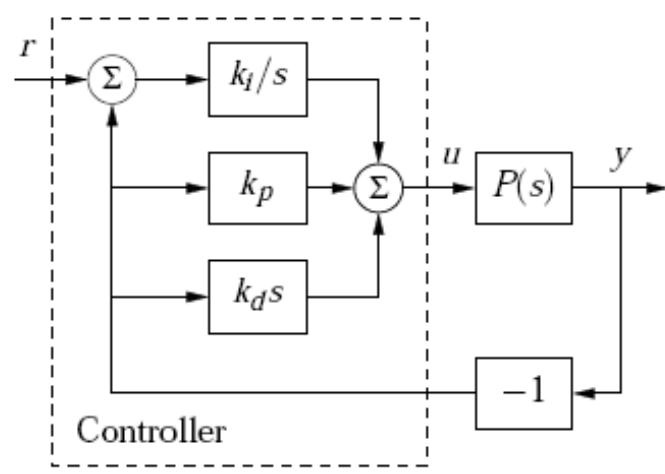

(b) PID using two degrees of freedom

- Gambar 2. Diagram blok sistem lup tertutup dengan kontroler PID.

Diagram blok sistem lup tertutup dengan kontroler PID ditunjukkan dengan Gambar 2, dan pada Gambar 2a. berdasarkan pada umpan balik dengan kesalahan pengontrol $e=r-y$ untuk dipergunakan pada aksi kontrol proporsional, integral dan derivatif. Pada Gambar 2b. memakai dua derajat kebebasan dengan dua input yaitu referensi $u$ dan output proses $y$. Aksi integral berdasarkan pada kesalahan sedangkan untuk aksi proporsional dan derivatif berdasarkan pada output proses $y$.

Sinyal umum $r$ disebut referensi pada masalah regulator atau dikenal sebagai setpoint pada literatur kontroler PID. Hubungan input-output untuk kontroler PID ideal dengan umpan balik kesalahan dinyatakan sebagai,

$$
u=k_{p} e+k_{i} \int_{0}^{t} e(\tau) d \tau+k_{d} \frac{d e}{d t}=k_{p}\left(e+\frac{1}{T_{i}} \int_{0}^{t} e(\tau) d \tau+T_{d} \frac{d e}{d t}\right)
$$

Kontroler PID awalnya disebut three-term controllers, mempunyai parameter-parameter penguatan proporsional $k p$, penguatan integral $k i$ dan penguatan derivatif $k d$. Konstanta waktu integral $T i$ dan konstanta waktu derivatif $T d$ kadang-kadang dipakai untuk menggantikan penguatan integral dan penguatan derivatif.

Respon kontroler P, PI dan PID terhadap perubahan bentuk undakan (step) ditunjukkan pada Gambar 3. Respon output proses terhadap beberapa input undakan untuk aksi proporsional dinyatakan pada Gambar 3a. Dengan tidak adanya bagian umpan maju (feedforward) yang ditunjukkan oleh Gambar 2a, maka output tak 
pernah mencapai nilai referensi (adanya kesalahan). Bertambahnya nilai penguatan proporsional $k p$ pada input akan mendekatkan output pada nilai referensi tetapi memunculkan osilasi yang semakin besar.
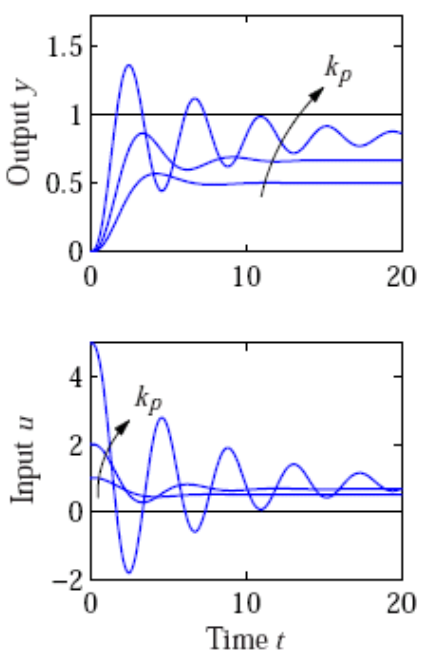

(a) Proportional control
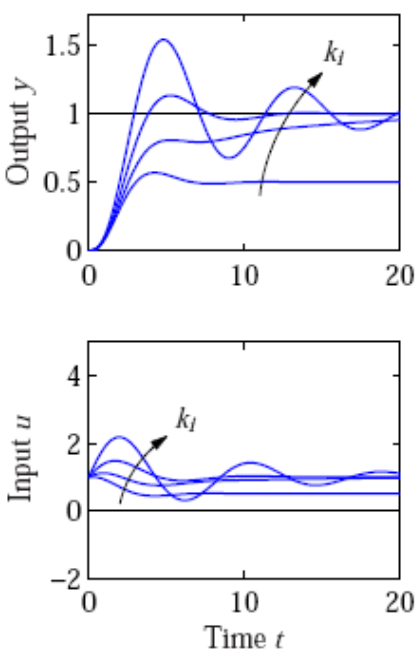

(b) PI control
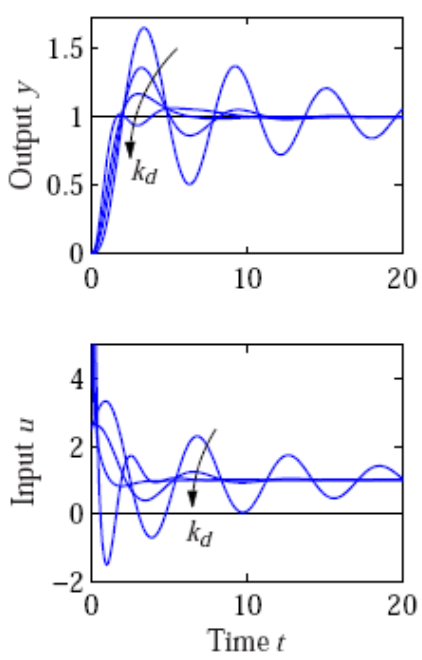

(c) PID control

- Gambar 3. Respon kontroler P, PI dan PID terhadap perubahan bentuk undakan (step).

Dengan asumsi dicapai keadaan tunak (steady state) pada saat $u=u_{0}$ dan $e=e_{0}$, maka Persamaan (15) menjadi $u_{0}=k p e_{0}+k i e_{0} t$, hasil ini kontradiktif kecuali $e_{0}$ atau $k i=0$. Dari hasil ini dapat diasumsikan tentang linieritas dari proses atau gangguan, dan dengan aksi integral diperoleh kesalahan keadaan tunaknya nol. Pada Gambar 3b, pengaruh aksi penguatan integral ki yang diperbesar akan membuat output kontroler mencapai nilai referensi dengan kesalahan nol, walaupun memunculkan osilasi.

Pengaruh sifat aksi derivatif ditunjukkan pada Gambar 3c, sistem berosilasi ketika tidak dipakai aksi derivatif dan respon transien lebih teredam dengan mengecilnya penguatan derivatif, $k d$. Kriteria akan memburuk bila penguatan derivatif terlalu tinggi (osilasi output bertambah besar). Ketika input sebuah undakan (step), output kontroler akan dibangkitkan oleh bagian derivatif sebagai impuls yang dapat dihindari dengan konfigurasi kontroler seperti pada Gambar 2a.

Meskipun kontrol PID dikembangkan dalam konteks aplikasi rekayasa, tetapi muncul juga dalam kehidupan nyata. Pelemahan gangguan melalui umpan balik pada sistem biologis sering disebut adaptasi, contohnya refleksi pupil bahwa mata beradaptasi terhadap perubahan intensitas cahaya, sehingga umpan balik dengan aksi integral analogi dengan adaptasi secara sempurna.

\section{KONTROL STEPSIZE}

Metode integrasi numerik yang dibahas sebelumnya (bagian 1, tulisan ini) menunjukkan peningkatan yang stabil dan akurasi lebih baik bila dipakai kontrol stepsize yang lebih kecil. Meskipun banyak pendekatan untuk kontrol stepsize ini, yang sering dipergunakan adalah proses dua langkah berikut ini [5].

Pertama, kontrol stepsize yang tepat didasari oleh pengetahuan yang tersedia tentang dinamika sistem, diantaranya entah digunakan model yang telah dilinearisasi atau eksperimental sistem fisik yang telah dilakukan, dan yang lainnya didasarkan pada beberapa pengetahuan tentang konstanta waktu yang tersedia. Aturan dasar praktis adalah memilih kontrol stepsize integrasi numerik sebesar seperempat hingga seperdelapan dari konstanta waktu sistem yang terkecil. Kedua, pengujian melalui sekmen waktu dengan mencoba sekmen waktu yang lebih kecil. Begitu kontrol stepsize dipilih, lakukan integrasi numerik dalam periode waktu dan input tertentu. Kemudian potong waktu integrasi menjadi dua dan ulangi integrasi numerik. Jika solusi tidak meningkat secara signifikan, kontrol stepsize awal yang dipilih. Bilamana solusinya sangat berbeda, kontrol stepsize yang lebih kecil harus dianggap sebagai kontrol stepsize kandidat dan langkah integrasi ini harus diulangi.

Kedua cara pendekatan tersebut di atas hanya memuaskan dalam menguji kontrol stepsize untuk kondisi yang telah diuji, jika input diubah atau sistem dijalankan melalui operasi yang durasinya berbeda akan timbul masalah. Bahkan untuk sistem linier, jika input fungsinya berubah secara bertahap, pemilihan sekmen waktunya harus sangat kecil, demikian pula untuk sistem nonlinier responsnya mungkin sangat berbeda untuk berbagai wilayah ruang operasi.

Terdapat pendekatan yang lebih maju untuk integrasi numerik yaitu melalui algoritma penyesuai interval integrasi melalui sebuah perkiraan kesalahan integrasi yang akan digunakan untuk memandu pemilihan interval. Algoritma ini dikenal sebagai adaptif-step-size algorithms yang sangat efisien dan telah menjadi standar dalam 
integrasi numerik $O D E$ (ordinary differential equations). Banyak variasi dari tema algoritma ini dan bila tertarik dapat membaca lebih lanjut untuk area ini pada referensi [6].

Prinsip-prinsip integrasi numerik diilustrasikan dengan metode Euler, interpretasi metode Euler adalah pendekatan derivasi dari fungsi melalui interval integrasi secara tetap, hal ini sebagai bentuk pertama dari perluasan dan derivasi deret Taylor. Bahwa metode Euler sebagai metode pendekatan orde pertama, untuk orde yang tinggi sering dipakai metode Euler yang diperluas (orde dua) dan metode Runge-Kutta orde empat. Setelah metode numerik dipilih, selanjutnya pemilihan stepsize dan aturan praktis adalah menghubungkan kontrol stepsize terintegrasi dengan parameter sistem seperti konstanta waktu. Kebanyakan sistem rekayasa dalam praktiknya dijelaskan oleh lebih dari satu persamaan diferensial, sehingga memerlukan kumpulan solusi persamaan diferensial.

Tinjau metode numerik pertama untuk menyelesaikan persamaan diferensial orde satu dengan bentuk [5],

$$
\frac{d x}{d t}=f(x, t)
$$

dengan kondisi awal $x\left(t_{0}\right)=x_{0}$.

Persamaan (16) menyatakan fungsi $f(x, t)$ dengan kemiringan $x(t)$.

Melalui pendekatan metode Taylor untuk sebuah derivasi kontinyu orde satu yang didefinisikan dengan,

$$
\begin{aligned}
& \frac{d x}{d t}=\lim _{\Delta t \rightarrow \infty} \frac{\left[x\left(t_{0}+\Delta t\right)-x\left(t_{0}\right)\right]}{\Delta t} \\
& \frac{d x}{d t} \approx \frac{\left[x\left(t_{0}+\Delta t\right)-x\left(t_{0}\right)\right]}{\Delta t}
\end{aligned}
$$

Estimasi nilai fungsi $x$ pada waktu $t_{0}+\Delta t$ adalah,

$$
x\left(t_{0}+\Delta t\right) \approx x\left(t_{0}\right)+\left.\frac{d x}{d t}\right|_{t_{0}} \Delta t
$$

Substitusi Persamaan (16) kepada Persamaan (19) akan memberikan pendekatan solusi,

$$
x\left(t_{0}+\Delta t\right) \approx x\left(t_{0}\right)+f\left(x_{0}, t_{0}\right) \Delta t
$$

Metode Euler didasarkan pada pendekatan persamaan terbatas dari turunan pertama $d x / d t$ kontinyu dan untuk integrasi numerik mengasumsikan kemiringan $x(t)$ konstan pada $t=t_{0}$ selama interval integrasi, $x(t)$ diekstrapolasi dari $t=t_{0}$ kepada $t=t_{0}+\Delta t$ dengan asumsi fungsi berupa garis lurus. Metode Euler ekivalen dengan bentuk pendekatan pertama dari deret Taylor, bahwa Persamaan (20) menyatakan algoritma rekursif untuk komputasi $x\left(t_{0}+k \Delta t\right)$ dengan $k=1,2, \ldots, N$. Sehingga prosedur solusi Euler dengan mencocokkan mulai dari waktu awal $t_{0}$ sampai waktu akhir $t_{f}=t_{0}+N \Delta t$ dengan langkah waktu yang konstan $\Delta t$.

Tinjau Persamaan diferensial berikut [7],

$$
\dot{x}=(1-2 t) x(t), \quad t>0, \quad x(0)=1
$$

dengan interval waktu $0 \leq t \leq 0,9$.

Persamaan (21) dapat dituliskan sebagai $\dot{x}_{n}=\left(1-2 t_{n}\right) x_{n}$, dan solusi sebenarnya

$$
x(t)=\exp \left[\frac{1}{4}-\left(\frac{1}{2}-t\right)^{2}\right]
$$
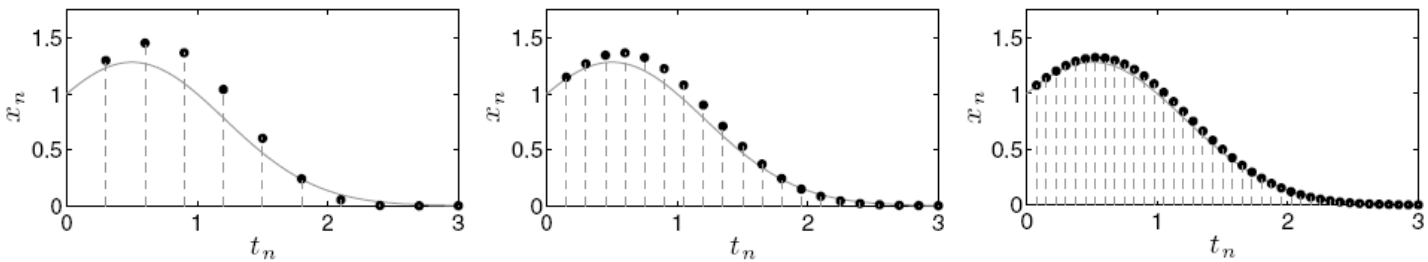

- Gambar 4. Solusi numerik Persamaan (22) dengan $h=0,3$ (kiri), $h=0,15$ (tengah) dan $h=0,075$ (kanan).

Kurva dengan garis nyata pada Gambar 4. menunjukkan solusi sebenarnya Persamaan (21) dan titik-titik pada kurva menyatakan solusi numerik untuk beberapa nilai $h$. Untuk nilai $h$ yang semakin kecil didapat kurva yang mirip dengan kurva solusi sebenarnya, pemilihan nilai $h$ sangat berpengaruh terhadap akurasi dan efisiensi dari hasil yang akan dicapai.

Bila kepada persamaan (21) diterapkan solusi numerik dengan adaptive-stepsize algorithm, maka didapat nilai stepsize,

$$
h_{\text {new }}=\left|\frac{(p+1) ! t o l}{x_{n}{ }^{p+1}}\right|^{1 /(p+1)}
$$

dan bila langkah ini diterima selanjutnya dipakai $h_{n+1}=h_{\text {new }}$ dan bila sebaliknya hitung ulang dengan memakai $h_{n}$ $=h_{\text {new }}$. Beberapa metode untuk memperbaiki solusi hasil simulasi diantaranya metode satu langkah, aturan trapesoidal, metode Runge-Kutta-23, RK-34, RK-45 dan sebagainya. Pada Gambar 4. tampak bahwa nilai stepsize semakin kecil akan menghasilkan akurasi yang tinggi tetapi perlu banyak perhitungan sehingga tidak efisien. 


\section{KONTROL STEPSIZE DAN AKSI KONTROLER PID}

Pada bidang sistem kontrol, sebuah kontroler dapat ditempatkan pada sistem open loop atau closed loop seperti pada Gambar 5. Fungsi kontroler bisa berdiri sendiri sebagai pengontrol atau dapat berfungsi sebagai pengontrol dan pembanding (komparator).

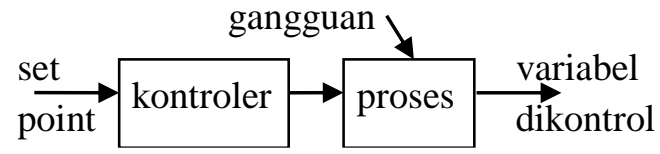

(a)

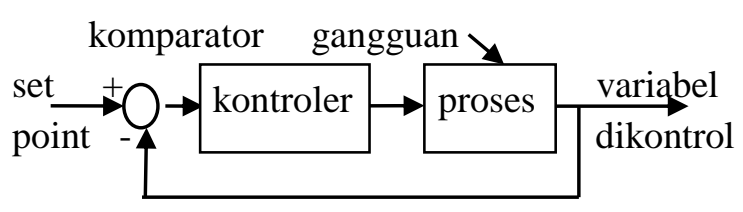

(b)

- Gambar 5. Diagram blok yang menyatakan hubungan kontroler dengan plant/proses pada

(a) sistem open-loop dan (b) sistem closed-loop.

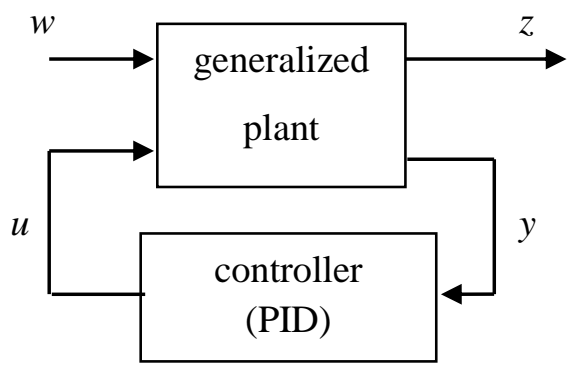

(a)

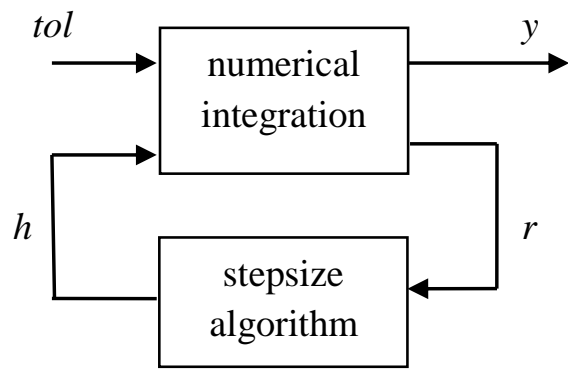

(b)

- Gambar 6. Pernyataan diagram blok dan ekivalensi antara, (a) sistem kontrol dengan kontroler (PID) dan, (b) kontrol stepsize pada integrasi numerik.

Pernyataan sebuah sistem kontrol dapat dinyatakan dengan Gambar 5, selain itu banyak pula yang menyatakannya seperti Gambar 6, dengan blok generalized plant dapat mencakup aktuator-aktuator yang dibangkitkan oleh input yang masuk kepada plant, sensor-sensor pengukur sinyal, konverter analog-digital dan yang lainnya. Pada Gambar 6a, blok kontroler berisi bagian yang dapat dirancang seperti, kontroler PID, perangkat rangkaian listrik, PLC (programmable logic controller), komputer berkemampuan umum atau perangkat lainnya. Sinyal-sinyal $w, z, u$, dan $y$ secara umum sebagai fungsi waktu, sinyal $w$ berasal dari luar yang mempengaruhi plan, bentuknya dapat berupa sinyal-sinyal referensi, gangguan-gangguan, noise sensor dan yang lainnya. Sinyal $z$ adalah semua sinyal yang dikontrol seperti, menelusuri kesalahan antara sinyal referensi dengan output plant, sinyal-sinyal aktuator sehingga nilai operasinya dalam batas tertentu dan yang lainnya. Sinyal $y$ dapat berupa output dari semua sensor, dan sinyal $u$ mencakup semua input yang dikontrol untuk mengaktifkan plant.

Pada Gambar 6b. diperlihatkan ekivalensi sistem kontrol dengan kontrol stepsize pada integrasi numerik, sehingga akan menghubungkan permasalahan sifat aksi kontroler PID dengan kontrol stepsize (bagian 2 dan 3 dari tulisan ini). Sinyal-sinyal pada Gambar 6a. dan Gambar 6b. akan ekivalen dengan,

- sinyal $w$ berubah menjadi tol (sebagai akurasi yang disyaratkan pada analisa numerik)

- sinyal $u$ sebagai output kontroler PID akan menjadi $h$ (stepsize) pada integrasi numerik

- sinyal $y$ sebagai input kontroler PID akan menjadi $r$ (estimasi kesalahan integrasi numerik)

- sinyal $z$ sebagai output plant akan berubah menjadi $y$ (solusi dari integrasi numerik)

- blok kontroler (PID), akan menjadi blok stepsize algorithm yang dipakai untuk mengontrol stepsize

- blok generalized plant akan menjadi blok numerical integration yang berisi komponen-komponen yang

dibutuhkan untuk perhitungan seperti, persamaan diferensial, metode yang digunakan diantaranya persamaan

Euler, deret Taylor, persamaan Runge Kutta dan estimasi kesalahan.

Dalam pandangan sistem kontrol (bagian 3, tulisan ini), telah diketahui karakteristik dari kontroler yang bersifat proporsional tak mampu menghilangkan kesalahan antara hasil simulasi dengan fungsi yang sebenarnya, dan upaya pada analisa numerik dengan langkah memodifikasi atau menggunakan metode-metode tertentu seperti adaptive-stepsize algorithm atau ukuran stepsize yang diubah dari terbesar sampai terkecil, bila semua upaya yang dilakukan masih bersifat proporsional akan tetap terjadi kesalahan seperti tampak pada Gambar 3a, bahwa nilai penguatan proporsional $\mathrm{kp}$ yang diperbesar akan mendekatkan output kontroler kepada nilai referensi tetapi memunculkan osilasi pada keadaan tunak (steady state) dan kesalahannya sama sekali tak dapat 
dihilangkan, hal ini konsekuensi dari kelemahan aksi proporsional walaupun dalam praktik aksi ini paling mudah diimplementasikan.

Pencarian solusi persamaan diferensial melalui metode integrasi numerik, banyak menggunakan pendekatan secara proporsional dan kelemahan lainnya adalah pendekatan pemilihan kontrol stepsize yang bersifat statik untuk memperoleh solusi yang bersifat dinamik. Untuk permasalahan yang bersifat dinamik pendekatannya harus bersifat dinamik dan salah satu penanganannya melalui pendekatan aksi kontroler proporsional-integral (PI) seperti tampak pada Gambar 3b atau Persamaan (15). Aksi penguatan integral ki yang diperbesar akan membuat output kontroler mencapai nilai referensi dan tanpa kesalahan saat kondisi steady state, walaupun memunculkan sedikit osilasi tetapi osilasi yang terjadi kecil sekali bila dibandingkan pada aksi proporsional. Pendekatan dengan sifat dinamik ini telah dilakukan oleh peneliti (bagian 1, tulisan ini) untuk sebuah persamaan diferensial tertentu dan diperlihatkan hasil yang diperoleh lebih baik dibandingkan penanganan secara statik.

Bila diinginkan hasil metode integrasi numerik mempunyai bentuk (trayektori) yang mirip dengan solusi sebenarnya, maka dapat digunakan sifat dari aksi kontroler proporsional-integral-derivatif (PID) walaupun pada pelaksanaannya akan muncul kendala saat pemilihan atau penyetelan harga parameter-parameter $k p, k i$ dan $k d$, tetapi hasil yang dicapainya akan sepadan karena diperoleh hasil integrasi numerik yang sangat mirip dengan solusi sebenarnya dan kesalahan yang relatif kecil sekali. Tampaknya masalah kontrol stepsize masih menjadi daya tarik untuk para peneliti, hal ini tampak dari masih banyaknya publikasi mengenai kontrol stepsize diantaranya, penyelesaian masalah persamaan diferensial orde satu dengan nilai awal menggunakan metode satu langkah A-stable yang tidak standar [8].

\section{KESIMPULAN}

Permasalahan dalam metode integrasi numerik diantaranya membutuhkan kontrol stepsize yang akan mempengaruhi keakurasian dan efisiensi. Secara sederhana perkiraan kontrol stepsize yang cukup tepat adalah berdasarkan pada pengetahuan dinamika sistem, berdasarkan perkiraan kesalahan integrasi untuk memandu pemilihan interval berikutnya, atau algoritma lainnya yang terus dikembangkan. Pendekatan mengontrol stepsize secara proporsional dan statik untuk suatu sinyal dinamik akan menghasilkan kesalahan antara hasil integrasi numerik dengan solusi sebenarnya.

Pada bidang sistem kontrol, telah dibuktikan sifat proporsional dari kontroler akan mempunyai kelemahan yaitu adanya osilasi dan kesalahan pada saat steady state (bagian 2, tulisan ini) walaupun sifat proporsional ini yang paling mudah diimplementasikan, dan pendekatan untuk sistem dinamik dapat dilakukan melalui aksi kontroler PI, PD atau PID yang memang pada dasarnya bersifat dinamik, dan pengaturan atau penyetelan nilai penguatan $k p, k i$ dan $k d$ akan berbeda untuk setiap kasus.

Melalui diagram blok Gambar 6. dan pembahasan pada bagian 4 dari tulisan ini, permasalahan pada integrasi numerik untuk kontrol stepsize adalah ekivalen dengan aksi kontroler PID pada bidang teknik kontrol, maka minimal secara teoritis kontrol stepsize dapat dianalisis melalui konsep sistem kontrol dan, karena penelitiannya masih berlanjut penulis belum dapat menyajikan uji numerik, tetapi kasus yang dibahas pada referensi [1] menyakinkan penulis bahwa kontrol stepsize ekivalen serta dapat dianalisis melalui konsep sistem kontrol yang melibatkan kontroler PID.

\section{DAFTAR REFERENSI}

[1]. K. Gustafsson, Stepsize Selection in Implicit Runge-Kutta Methods Viewed As A Control Problem. IFAC 12 ${ }^{\text {th }}$ Triennial World Congress. Sydney, Australia, 1993.

[2]. Hairer, E., S.P. Norsett, and G. Wanner, Solving Ordinary Differential Equations I - $\quad$ Nonstiff Problems, vol 8. Springer Series in Computational Mathematics. Springer-Verlag. 1987.

[3]. K. Gustafsson, "Control of Error and Convergence in ODE Solver", PhD Thesis, Departement of Automatic Control, Lund Institute of Technology, 1992.

[4]. Karl Johan Astrom and Richard M. Murray, Feedback Systems : An Introduction for Scientists and Engineers, Princeton University Press, 2008.

[5]. Bohdan T. Kulakowski, et al., Dynamic Modeling and Control of Engineering, Cambridge University Press, The Edinburgh Building, Cambridge CB2 8RU, UK, 2007.

[6]. W. H. Press, et al., Numerical Recipes in C (Cambridge University Press, New York, 1988), Chap. 15.

[7]. David F. Griffiths and Desmond J. Higham, Numerical Methods for Ordinary Differential Equations, Springer-Verlag London Limited, 2010.

[8]. Higinio Ramos, et al., Solving First-order initial-value problems by using an explicit non-standard A-stable on-step method in variable step-size formulation, Applied Mathematics and Computation Jurnal 268, 2015. 